\title{
Relationship between Motivation, Academic Self-concept and Academic Achievement amongst Students at a Ghanaian Technical University
}

\author{
Juatice Solomon Korantwi-Barimah (Corresponding author) \\ Faculty of Business and Management Studies, Sunyani Technical University, Ghana \\ Email: korantwi75@yahoo.com
}

Alex Ofori

Faculty of Business and Management Studies, Sunyani Technical University, Ghana

\author{
Eric Nsiah-Gyabaah
}

Department of Accountancy, Sunyani Technical University, Ghana

Allan M. Sekyere

Department of Accountancy, Sunyani Technical University, Ghana

Received: December 15, 2016 Accepted: January 17, 2017 Published: February 18, 2017 doi:10.5296/ijhrs.v7i1.10459 URL: http://dx.doi.org/10.5296/ijhrs.v7i1.10459

\begin{abstract}
Purpose- This study explores the relationship between motivation, academic self-concept and academic achievement amongst Sunyani Technical University students. Gender differences between academic self-concept, motivation and academic achievement were also investigated.

Design/methodology/approach- The study utilized a quantitative cross-sectional survey design. A self-constructed questionnaire was used to collect data from 193 final year Higher National Diploma students from four faculties at the university, using simple random sampling techniques. Criterion for academic achievement was a mark which students themselves reported. Data were analyzed using SPSS16 by means of Pearson Correlation
\end{abstract}


coefficient

Finding-The study found that there were significant correlations between academic self-concept, motivation and academic achievement of students. It was also found that female students are significantly more motivated than their male counterparts.

Conclusion: The study concludes that the findings justify the importance of academic self-concept and motivation to academic achievement. Some recommendations were made regarding the enhancement of academic self-concept and motivation amongst students to improve their performance.

Value/originality-Since the study is first of its kind critically exploring the relationship between motivation, academic self-concept and academic achievement amongst students at a Ghanaian Technical University, management in the tertiary sector may find the findings and conclusions useful. The findings trigger more research interests among scholars who might be interested in this field.

Keywords: Ghanaian technical university, Academic self-concept., Motivation, Academic achievement.

\section{Introduction}

The Government's policy to convert Ghana's polytechnics into technical universities was to help reposition them as strategic institutions for the training of highly skilled human resource to drive the nation's socio-economic development (Technical Universities Act, 2016 (Act 992). Consequently, efforts and resources have been put in place to improve the standards of learning through infrastructural development at the universities. Similarly, Ankomah et al. (2005) contend that due to the valuable role of education to national development, successive governments of Ghana have made several efforts to improve the standards of learning through infrastructural development at the education sector among other policy initiatives. That notwithstanding, the standard still remains low, especially, at the high school level (MOE, 2008). This has prompted several research into more effective ways of improving academic standards and have found out that inadequate motivation for students of higher learning (Sikhwari, 2014), students' low personality and self- concept (More, 1973), feeling of inadequacy (Callahan, 1971) and lack of motivation and self-confidence (Aiken, 1976) among other factors as a disincentives to learning and academic achievement. Brown et al. (1998) contend that stimulating motivation among students of higher learning still remains a challenge as some students' enthusiasm for learning is unpredictable. A study by Marsh and Craven (1997) into the relationship between academic achievement and self-concept established a positive correlation. In Ghana, lack of motivation has been one of the most critical factors affecting learning in institutions of higher learning, especially in the technical universities. As argued by Awan et al. (2011), lack of motivation is "a big hurdle in learning and a pertinent cause in the deterioration of education standards." Studies carried out in the West have widely investigated the academic motivation. However, a few researchers in the academic field have studied the role of motivation in academic achievement in the tertiary 
institutions in Ghana. It is therefore imperative to explore factors such as motivation and self-concept which have positive relationship with academic performance of these students. Concerning the existing gap in the academic motivation of students, this study has explored the relationship between motivation, academic self-concept and academic achievement amongst Sunyani Technical University students. This study would provide necessary information for stakeholders in the higher education to formulate policies that will aid academic performance of students.

\subsection{Objectives of the Study}

This study sought to explore the relationship between motivation, academic self-concept and academic achievement of students of Sunyani Technical University, Ghana. Specifically, the study sought:

-To find out the relationship between motivation, academic self-concept and academic achievement.

-To determine gender differences for motivation, academic self-concept and academic achievement.

\subsection{Hypotheses}

The following five null hypotheses were tested for significance level in the study:

HO1: There is no significant difference between the average self-concept scores of male and female students.

HO2: There is no significant difference between the average motivation scores of male and female students.

HO3: There is no significant difference between average achievement scores of male and female students.

HO4: There is no significant correlation between achievement and self-concept scores of students.

HO5: There is no significant correlation between achievement and motivation scores of students.

\section{Literature Review}

\subsection{Motivation}

As pointed out by Brown et al. (1998), the challenge in higher education has always been to stimulate, engender and enhance the motivation of those students whose enthusiasm for learning is dubious. Campbell \& Pritchard (1976) defined motivation as being the set of psychological processes that cause the initiation, direction, intensity, and persistence of behavior. Pintrich and Schunk (2002) regard motivation as an integral part of learning. The authors further argue that students who are motivated to learn about a topic are keen to engage in activities they believe will help them learn, such as attending carefully to the 
instruction, taking notes to facilitate subsequent studying, checking their level of understanding and asking for help when they do not understand the material. In contrast, students who are unmotivated to learn are not enthusiastic in their learning efforts. They may be inattentive during the lesson and not organise or revise the learning material. They may not monitor their level of understanding or ask for help when they do not understand what is being taught. Awan et al. (2011) define motivation as internal condition that stimulates, direct and maintains behaviour, and they believe that there is a strong relationship between learning and motivation.

According to Pintrich and Schunk (2002), motivation influences learning and performance and what students do and learn influence their motivation. It is assumed, however, that people differ in their need to achieve in situations that call for excellence (Muola, 2010). Gesinde, cited in Muola (2010), argues that the urge to achieve varies from one individual to the other. He adds that those who have high achievers as their role models in their early life experience would develop a high need for achievement, while those who have low achievers as their role models will hardly develop the need for achievement. According to Tella (2007), the issue of motivating learners is seen as an important aspect of effective learning. Fontana, in Tella (2007), argues that satisfactory school learning is unlikely to take place in the absence of sufficient motivation to learn.

\subsection{Academic Self-concept}

According to Drew and Watkins (1998), self-concept is a psychological construct which refers to a cluster of ideas and attitudes an individual holds about himself/herself. Mwamwenda (1995) regards self-concept as a person's way of perceiving himself/herself and may be either positive or negative. In this study, academic self-concept is regarded as the main component of the self-concept. Cokley (2000) defines academic self-concept as "attitudes, feelings and perceptions relative to one's intellectual or academic skills". The same author considers academic self-concept to be how a student views his/her academic ability when compared with other students. Students attach a lot of importance to academic ability, so that self-acceptance is based largely on cognitive abilities (Cokley 2000). A student with a negative academic self-concept, for example, might just avoid studying hard because he would regard the subject content as too difficult. McCoach and Siegle (2003) point out that academic self-concept involves a description and an evaluation of one's perceived academic abilities and encompasses beliefs of self-worth associated with one's perceived academic competence. These authors state further that students compare their own performance with that of their classmates (an internal comparison). This implies that students' academic self-concepts are determined by their perceptions of their academic ability in an area as well as their assessment of their academic standing relative to their classmates (McCoach and Siegle 2003). The same authors regard academic self-concept as a significant predictor of academic achievement.

In an investigation of academic achievement in African-American college students (Cokley 2000), there was a strong positive correlation between academic self-concept and grade point average (GPA) scores. It was also found that students with higher GPAs had statistically 
higher academic self-concept scores than students with lower GPAs. In a study by Kobal and Musek (2001), French students turned out to be more successful in school than Slovenians and it is further stated that the findings support the possibility that the higher academic achievement of French students is mostly related to their higher academic self-concept. Chowdhury and Pati, in Awan et al. (2011) assert that "self-concept plays a significant role in the educational process when a child is accepted, approved, respected and liked, and one will have an opportunity to acquire an attitude of self-acceptance and respect for oneself'. According to Wang and Lin, in Awan et al. (2011), self-concept was seen as the general confidence that individuals felt about themselves and the levels of an individual's self-concept predict the extent to which he or she was able to accomplish academic tasks successfully or unsuccessfully. They further argue that much of the earlier interest in the self-concept versus achievement relationship stem-med from the belief that academic self-concept had motivational functions and thus, changes in academic self-concept would lead to changes in subsequent academic achievement.

\subsection{Academic Achievement}

According to Chowdhury and Pati, in Awan et al. (2011), academic achievement is defined by examination marks, teachers' given grades and percentiles in academic subjects. Rickson (1977) views achievement within any context as performance relative to some standard and he further states that academic achievement and other dimensions of learning can be measured by a variety of yardsticks or measuring instruments, the results of which are types of scores, ranks or grades. Van den Aardweg and Van den Aardweg (1988) regard achievement as a product which can be measured by means of achievement tests and is usually associated with mental success. For this study, the respondents' examination results were used as measures of academic achievement.

\subsection{Theoretical Framework}

\subsubsection{Self-determination Theory (SDT) of Motivation}

Self-determination theory (SDT) is one of the theories developed for understanding individuals' motivation (Deci and Ryan, in Eymur and Geban 2011). According to Eymur and Geban (2011), STD suggests that the impetus of motivated behaviour is having the experience of choice (autonomy) and emotion of efficacy in actions (competence), and the value attached to important others in the individual's environment (relatedness). These authors further point out that the most differentiating characteristic of SDT from other motivation theories is that it suggests motivation as a multidimensional concept that not only varies in level, but also kind. Deci and Ryan, in Eymur and Geban (2011), proposed that there are three main types of motivation, namely intrinsic motivation, extrinsic motivation and amotivation. Intrinsic motivation refers to being engaged in an activity for itself and for the pleasure and satisfaction derived from participation (Deci, in Eymur and Geban 2011). Intrinsic motivation is widely regarded as the highest level of motivation as it is completely from within an individual (Grolnick, in Eymur and Geban 2011). Extrinsically motivated learners' behaviours are shaped by external factors such as rewards and punishment (Karsenti and Thibert, in Eymur and Geban 2011). The absence of any self-determination is called 
amotivation (Eymur and Geban 2011). Cokley, in Eymur and Geban (2011), defines amotivation as the lack of both extrinsic and intrinsic motivation. This author further indicates that a student who is amotivated cannot, for example, explain why he/she attends school.

\subsubsection{The Self-concept and Academic Performance Model}

Educational psychology has been concerned with analysing different types of relationships that exist between self-concept and academic performance (Sanchez and Roda, 2004). The authors identified the following four possible patterns or causal models between self-concept and academic performance:

\section{(i) Academic Performance Determines Self-concept}

Academic experiences of success or failure significantly affect the student's self-concept and self-image more than vice versa. Given that the influencing variable is academic performance, psycho-pedagogic interventions should be given priority to modifying the students' level of achievement, since this will contribute to changing the level of self-concept.

(ii) Level of Self-concept Determines the degree of Academic Achievement

Given that self-concept is what determines levels of academic achievement, and self-concept in turn can be strongly influenced by acceptance levels provided by the student's significant others, we can infer that it would be possible to increase levels of school performance by optimizing levels of self-concept and very specifically levels of perceived competence.

(iii) Self-concept and Academic Performance Influence Each Other

The third model of casual relationship postulates that self-concept and academic performance influence and determine each other mutually. This means that success in academic tasks can lead to the development of a positive self-concept while, on the other hand, failure can lead to experiencing feelings of rejection, isolation, worthlessness and consequently a negative self-concept.

\section{Methodology}

The study was a quantitative research which employed a cross-sectional survey design. According to Creswell (2012), this design has the advantage of measuring current attitudes, beliefs, opinions or practices and it also provides information in a short amount of time.

The study targeted all the third year Higher National Diploma (HND) students in four of the faculties at the university as the population for investigation. A total of 193 (83 males and 110 females) students were selected, using simple random sampling technique from the faculties. This was to ensure that any individual in the list has an equal probability of being selected from the population (Creswell 2012).

The study used a self-constructed survey instrument. The survey instrument consists of 32 questions using a 4-point Likert scale. The items in the questionnaire were scaled items in the form of a question or statement followed by a scale of potential responses. The participants 


\section{Macrothink}

International Journal of Human Resource Studies

ISSN 2162-3058

2017, Vol. 7, No. 1

had to select the response on the scale that best reflects their beliefs or opinions about the statement. The researchers personally administered the questionnaires to the students in the four faculties on various occasions during normal class periods. A period of forty minutes was sufficient as it took approximately thirty minutes to answer the questionnaire in each session.

Reliability was established by calculating the alpha reliability coefficient for both the self-concept section and motivation section. The reliability coefficients were 0.25 and 0.57 for self-concept and motivation respectively. According to Pienaar (1994), when an instrument is developed, its reliability should be as close to 1 as possible. With these figures, the questionnaire was regarded as a reliable measuring instrument.

Data were analysed using the Statistical Package for Social Sciences (SPSS). To determine whether males and females differ significantly, a t-test was used to compare the averages. Pearson's Product Moment Correlation was used to determine the correlation between the achievement scores of the students and their scores for self-concept and motivation.

Approval for conducting the research was obtained from the Research and Development Directorate at the university. All the participants were informed about the study, and assured of their confidentiality. Participation in the research was voluntary, and participants could terminate their participation any time without any penalty.

\section{Results}

The analysis in Table 1 shows that the distribution of the sample based on the gender was fairly distributed between male and female respondents (males, $43.01 \%$ and females, $56.99 \%)$.

Table 1: Sex of Respondents

\begin{tabular}{lll}
\hline Gender & Frequency $(\mathbf{N})$ & Percentage $(\boldsymbol{\%})$ \\
\hline Males & 83 & 43.01 \\
Females & 110 & 56.99 \\
\hline Total & $\mathbf{1 9 3}$ & $\mathbf{1 0 0}$ \\
\hline
\end{tabular}

In terms of faculty affiliated, the analysis shows that the majority (61), representing $31.6 \%$ of respondents were from the faculty of Business and Management Studies. With the remaining students, 44 (22.8\%) were from Applied Sciences, 36 (18.6\%) from Built Environment and $52(26.9 \%)$ from Engineering. This is presented in Table 2. 


\section{Macrothink

Table 2: Faculty/School of Respondents

\begin{tabular}{llll}
\hline Faculty & & Frequency $(\mathbf{N})$ & Percentage (\%) \\
\hline $\begin{array}{l}\text { Business \& } \\
\text { Studies }\end{array}$ & Management & 61 & 31.61 \\
$\begin{array}{l}\text { Applied Sciences } \\
\text { Technology }\end{array}$ & $\&$ & 44 & 22.80 \\
Build Environment & 36 & \\
Engineering & 52 & 18.65 \\
\hline Total & $\mathbf{1 9 3}$ & 26.94 \\
\hline
\end{tabular}

\subsection{Testing the Hypotheses}

In order to test the hypotheses stated earlier, a correlation analysis was conducted to understand the relationships between the variables of the study. Tables below depict the means, standard deviations, and $r$-values of the significance of the relationships.

Hypothesis 1: There is no significant difference between the average self-concept scores of male and female students

The t-value in Table 3 shows that males and females do not differ significantly regarding their average self-concept ( $\mathrm{p}>0.05)$.

Hypothesis 2: There is no significant difference between the average motivation scores of male and female students.

The t-value in Table 3 shows that there is a significant difference between the average motivation of males and females $(\mathrm{p}<0.05)$. Females have higher motivation scores than males.

Hypothesis 3: There is no significant difference between average achievement scores of male and female students.

The t-value shows that there is no significant difference between males and females regarding their average achievement scores ( $p>0.05)$. The data are shown in Table 3. 


\section{IIMacrothink}

International Journal of Human Resource Studies

ISSN 2162-3058 2017, Vol. 7, No. 1

Table 3: The difference between the mean scores of Academic self-concept, motivation and achievement of male and female students

\begin{tabular}{|c|c|c|c|c|c|c|c|}
\hline Variable & Gender & $N$ & Mean & $S D$ & $T$ & $D f$ & $p$ \\
\hline \multirow[t]{2}{*}{$A S C$} & Male & 83 & 3.180 & 0.382 & 0.806 & 191 & $\begin{array}{l}\mathrm{p}> \\
0.05\end{array}$ \\
\hline & Female & 110 & 3.224 & 0.362 & & & \\
\hline \multirow[t]{2}{*}{$M O T$} & Male & 83 & 3.306 & 0.307 & 2.642 & 191 & $\begin{array}{l}\mathrm{p}< \\
0.05\end{array}$ \\
\hline & Female & 110 & 3.414 & 0.259 & & & \\
\hline \multirow[t]{2}{*}{$A C H$} & Male & 83 & 56.08 & 7.092 & 0.470 & 191 & $\begin{array}{l}\mathrm{p}> \\
0.05\end{array}$ \\
\hline & Female & 110 & 56.55 & 6.483 & & & \\
\hline
\end{tabular}

Hypothesis 4: There is no significant correlation between achievement and self-concept scores of students.

The results show that there is a significant correlation between achievement and the self-concept of students. The data are shown in Table 4.

Table 4: Correlations between scores of academic self-concept, motivation and achievement

\begin{tabular}{llll}
\hline & ACH & MOT & ASC \\
\hline ACH & 1.000 & $0.215^{*}$ & $0.358^{*}$ \\
MOT & & 1.000 & $0.555^{*}$ \\
ASC & & & 1.000 \\
\hline
\end{tabular}

*Significant at 0.01 level

Hypothesis 5: There is no significant correlation between achievement and motivation scores of students.

The results show that there is a significant correlation between achievement and motivation scores of students. The data are shown in Table 4 above. 


\section{Discussion}

The result of the second hypothesis, which compares motivation scores of male and female students, was found to be significant. Females have higher motivation scores than males. According to Brophy (1998), boys generally place less value on engaging in academic activities than girls do, so that the quality of their engagement is more variable. Awan et al. (2011) state that girls have been found by several studies to be more motivated and to be higher achievers than boys. Hotulainen and Schofield, in Awan et al. (2011), explain the same results in their study that girls were found to generally outperform boys and that boys consistently showed lower levels of academic competence and lower GPAs than their female counterparts. In another study whose aim was to examine the motivational differences between male and female students, females were found to be more motivated than males in all motivational subscales (Eymur and Geban 2011).

The result of the fourth hypothesis shows a significant correlation between achievement and the self-concept of students. A study by Barker et al. in Awan et al. (2011), a positive and statistically significant correlation was found between self-concept and academic achievement. McCoach (2002) indicates that academic selfconcept is a significant predictor of academic achievement. The same author further states that as much as one third of the variance in achievement can be accounted for by academic self-concept alone. In a study to investigate the relationship between self-beliefs, academic background and achievement of adolescent AsianAmerican students in post-secondary education (House 1997), academic self-concept was found to be a significant predictor of Asian-American students' subsequent academic performance. In another study, academic self-concept was found to be directly and significantly related to the deep rather than the surface learning approach (Drew and Watkins 1998).

The result of the fifth hypothesis shows that there is a significant correlation between achievement and motivation scores of the students. Karsenti, in Eynur and Geban (2011), found significant relation between school achievement (GPA) and motivation. Besides, past researches (Eymur and Geban) reported that extrinsic motivation was generally negatively related to achievement whereas intrinsic motivation positively related with achievement. A study by Goldberg and Cornell (1998) revealed statistically significant correlation between intrinsic motivation and academic achievement. Mnyandu (2001) found a significant positive correlation between intrinsic motivation and learners' performance. In a study to examine the pattern of motivation associated with school achievement, intrinsic motivation correlated significantly with grade point average (GPA) (Bergin 1987).

\section{Conclusion}

The study concludes that academic self-concept and motivation are important to academic achievement of students. More importantly, academic self-concept and motivation cannot be treated as separate entities, but as mutually dependent factors. It is therefore necessary to give adequate attention to the enhancement of academic self-concept and motivation when offering psycho-educational mediations in order to improve academic performance of students. 


\section{Implications}

This study consists of many positive implications for HEIs where it confirms that self-concept and motivation are central to academic achievement of students. Motivational factors have crucial role in academic achievement and since academic achievement of students is related to the society's development, it is suggested that more attention be paid to the components of motivation by administrators and educational planners. Further, since this study was confined to only four faculties of the university, its results should be generalized to other faculties and universities with caution.

\section{Recommendations}

According to the results of this study and the implications arising thereof, the following recommendations and suggestions are proposed. The recommendations are related to the strategies that policy makers and educational administrators can exploit in their future plans to improve academic self-concept, motivation and academic achievement of students within the technical universities in Ghana. The recommendations are that:

- Lecturers should focus on motivational strategies that will involve students in academic activities for improving their overall performance.

- Lecturers and educators must focus on intrinsic motivation which will have greater impact on students in achieving high academic performance in the absence of external rewards.

- Academic counselors should provide students with sufficient emotional and academic support to enhance their self-concept and achievement.

- Students should be exposed to and participate in self-esteem and positive self-concept enhancement programmes to help improve their learning outcomes.

\section{Limitations and Suggestions for Further Studies}

There are several limitations in this study, which offer directions for further research. The scope of the study is limited as it was conducted among only the final year students from four faculties in the university, which means the results and their interpretation cannot be generalized for other faculties or HEIs. It is obvious that the study sampled only one technical university. This limitation suggests that future research works should sample more than one HEI to include the remaining HEIs nationwide. This inclusion is necessary for the increment of precision level, the validity of the conclusions reached, generalizability of the findings and meeting the requirement of reasonable representativeness.

It is recommended that further research be conducted to investigate the relationship between self-concept and achievement in specific academic subjects. Further research could also be done to develop programmes for enhancing self-concept and motivation among students in other technical universities. 


\section{Macrothink}

\section{References}

Ankomah, Y., Koomson, J., Bosu, R. \& Oduro, G K.T. (2005). Implementing Quality Education in Low Income Countries University of Cape Coast- Ghana. Institute for Educational Planning and Administration. p.14

Awan RUN, Noureen I, Naz A 2011. A study of relationship between achievement motivation, self-concept and achievement in English and Mathematics at secondary level. International Education Studies, 4(3): 72-79.

Bergin DA 1987. Intrinsic Motivation for Learning, Outof-school Activities, and Achievement. PhD Thesis, Unpublished. Michigan: Stanford University.

Brophy J 1998. Motivating Students to Learn. Michigan State University: McGraw-Hill.

Brown S, Armstrong S, Thompson I 1998. Motivating Students. London: Kogan Page Limited.

Cokley K 2000. An investigation of academic self-concept and its relationship to academic achievement in AfricanAmerican college students. Journal of Black Psychology, 26(2): 148-164.

Creswell JW 2012. Educational Research: Planning, Conducting and Evaluating Quantitative and Quantitative and Qualitative Research. New Jersey: Pearson Education, Inc.

Deci, E. L., \& Ryan, R. M. (1985). Intrinsic Motivation and Self-Determination in Human Behavior (Perspectives in Social Psychology). Plenum Press.

Denhardt, R. B., Denhardt, J. V., \& Aristigueta, M. P. (2008). Managing Human Behavior in Public and Nonprofit Organizations. Sage Publications, Inc. Journal of Personality and Social Psychology, 47, 944952.

Drew PY, Watkins D 1998. Affective variables, learning approaches and academic achievement: A casual modelling investigation with Hong Kong tertiary students. British Journal of Educational Psychology, 68: 173-188.

Eymur G, Geban O 2011. An investigation of the relationship between motivation and academic achievement of preservice Chemistry teachers. Education and Science, 36 (161): 246-255.

Goldberg MD, Cornell DI 1998. The influence of intrinsic motivation and self-concept on academic achievement in second-and third-grade students. Journal for the Education of the Gifted, (2): 179-205.

House JD 1997. The relationship between self-beliefs, academic background, and achievement of adolescent Asian-American students. Child Study Journal, 27(2): 94-111.

Kobal D, Musek J 2001. Self-concept and academic achievement: Slovenia and France. Personality and Individual Differences, 30: 887-899. 


\section{Mll Macrothink \\ International Journal of Human Resource Studies \\ ISSN 2162-3058 \\ 2017, Vol. 7, No. 1}

McCoach DB 2002. A validation study of the school attitude assessment survey. Measurement and Evaluation in Counselling and Development, 35: 66-77.

McCoach DB, Siegle D 2003. The structure and function of academic self-concept in gifted and general education students. Roeper Review, 25(2): 61-65.

Mnyandu PT 2001. The Relations between Self-determination, Achievement Motivation and Academic Achievement.MA Dissertation, Unpublished. Pretoria: University of South Africa.

Muola JM 2010. A study of the relationship between academic achievement motivation and

home environment among standard eight pupils. Educational Research and Reviews, 5(5): 213-217.

Mwamwenda TS 1995. Educational Psychology: An African Perspective. Durban: Butterworth.

Pintrich PR, Schunk DH 2002. Motivation in Education: Theory, Research and Application. New Jersey: Pearson Education, Inc.

Sanchez FJP, Roda MDS 2004. Relationship between selfconcept and academic achievement in primary students. Electronic Journal of Research in Educational Psychology and Psychopedagogy, 1(1): 95-120.

Tella A 2007.The impact of motivation on student's academic achievement and learning outcomes in Mathematics among secondary school students in Nigeria. Eurasia Journal of Mathematics, Science and Technology Education, 3 (2): 149-156.

Van den Aardweg E M, Van den Aardweg E D 1988.

\section{Copyright Disclaimer}

Copyright for this article is retained by the author(s), with first publication rights granted to the journal.

This is an open-access article distributed under the terms and conditions of the Creative Commons Attribution license (http://creativecommons.org/licenses/by/3.0/). 